\title{
電解精製浴からの電析銅の表面粗度および 均一電着性に及ぼす添加剤の相乗効果
}

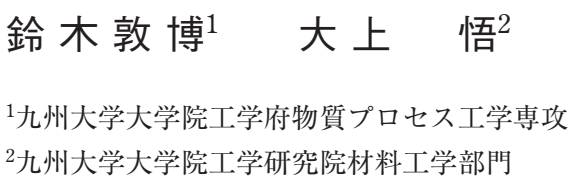 \\ ${ }^{3}$ 九州産業大学工学部物質生命化学科
}

J. Japan Inst. Met. Mater. Vol. 81, No. 7 (2017), pp. 358-365

(C) 2017 The Japan Institute of Metals and Materials

\section{Synergistic Effect of Additives on the Surface Roughness and Throwing Power of Copper Deposited from Electrorefining Solution}

\author{
Atsuhiro Suzuki ${ }^{1}$, Satoshi Oue ${ }^{2}$, Shigeo Kobayashi ${ }^{3}$ and Hiroaki Nakano ${ }^{2}$ \\ ${ }^{1}$ Department of Materials Process Engineering, Kyushu University, Fukuoka 819-0395 \\ ${ }^{2}$ Department of Materials Science \& Engineering, Kyushu University, Fukuoka 819-0395 \\ ${ }^{3}$ Department of Applied Chemistry and Biochemistry, Kyushu Sangyo University, Fukuoka 813-8503
}

\begin{abstract}
To elucidate the synergistic effect of gelatin, thiourea and chloride ions on the surface roughness, throwing power and polarization curves for $\mathrm{Cu}$ deposition from electrorefining solution, $\mathrm{Cu}$ electrodeposition was performed at a current density of $200 \mathrm{~A} \cdot \mathrm{m}^{-2}$

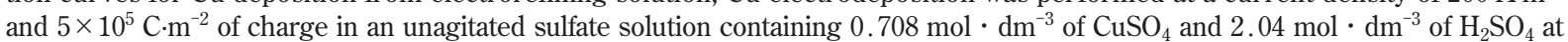
a temperature of $60^{\circ} \mathrm{C}$. In solutions containing three kinds of additives such as gelatin, thiourea and chloride ions, the surface roughness of deposited $\mathrm{Cu}$ decreased with increasing the concentration of thiouea and gelatin and decreasing the chloride ions. On the other hand, the throwing power of deposited $\mathrm{Cu}$ was improved with decrease in thiourea and increase in gelatin in solutions containing three kinds of additives. The throwing power of deposited $\mathrm{Cu}$ was significantly improved in solution containing both gelatin and chloride ions. The polarization resistance $\mathrm{d} E / \mathrm{d} i$ for $\mathrm{Cu}$ deposition increased in solution containing both gelatin and chloride ions, which resulting in improvement of throwing power of $\mathrm{Cu}$ deposition. As small amounts of thiourea have a depolarization effect on $\mathrm{Cu}$ deposition, a leveling effect is expected owing to the promotion of deposition at recesses. [doi:10.2320/jinstmet.J2017015]
\end{abstract}

(Received March 16, 2017; Accepted April 20, 2017; Published June 2, 2017)

Keywords: copper, electrorefining, electrolysis, gelatin, thiourea, chloride ions, throwing power, surface roughness polarization curve, depolarization

1. 緒言

$\mathrm{Cu}$ の電解精製では，㓌極表面を平滑にするとともに不純物 の共析を抑制するため, 電解液にゼラチン1-3), チ才尿素が添 加され，また陽極からのスライムの形成を容易にするため塩 化物イオンも加えられる. 電解液にゼラチン, チ才尿素, 塩 化物イオンを添加すると, 㓌極電位が卑に移行し, 電析物の 結晶粒が細かくなる ${ }^{4-8)}$. 著者らは, これまでに $\mathrm{Cu}$ の電解精 製におけるゼラチン，ポリエチレングリコールといった直鎖 状高分子添加剤の影響 9,10$)$, チ才尿素の影響 ${ }^{11,12)}$, 高分子添加 剂と塩化物イオン ${ }^{13-15)}$ の相乗効果 ${ }^{16)}$ について報告した。 しか し, 電析 $\mathrm{Cu}$ の表面粗度, 均一電着性に及ぼすゼラチン, チ

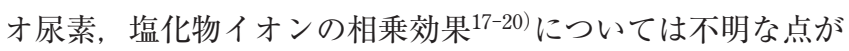
多い. そこで本研究では, 電析初期の $\mathrm{Cu}$ (膜厚 : 約 $18 \mu \mathrm{m}$ )の 表面形態, 表面粗度, 均一電着性に及ぼす添加剤の相乗効果 について調査した. 均一電着性は, 電析 $\mathrm{Cu}$ の膜厚プロファ イルを測定して, 定量的に評価した。 また，表面粗度，均一 電着性に及ぼす添加剤の効果を考察するため, $\mathrm{Cu}$ 電析の分極
曲線に及ぼすゼラチン, チオ尿素, 塩化物イオンの影響を調 査した。

\section{2. 実 験 方 法}

Table 1 に $\mathrm{Cu}$ 電解における添加剤の効果を調查するための 電解液組成および電解条件を示す． $\mathrm{Cu}$ 電解精製の基本液組成 は $\mathrm{CuSO}_{4} \cdot 5 \mathrm{H}_{2} \mathrm{O} 0.708 \mathrm{~mol} \cdot \mathrm{dm}^{-3}, \mathrm{H}_{2} \mathrm{SO}_{4} 2.04 \mathrm{~mol} \cdot \mathrm{dm}^{-3}$ であ る.この溶液に有機添加剂としてゼラチン $($ ニッピペプタイ ド, PA-10, 分子量 20000$)$ を $0.171,1.71,17.1 \mathrm{mg} \cdot \mathrm{dm}^{-3}$ (標準 濃度 $\left.1.71 \mathrm{mg} \cdot \mathrm{dm}^{-3}\right)$ ， チ才尿素を $0.0023 \sim 2.3 \mathrm{mmol} \cdot \mathrm{dm}^{-3}($ 標 準濃度 $0.023 \mathrm{mg} \cdot \mathrm{dm}^{-3}$ ) 添加した. 塩化物イオンとして塩酸を $0.165,1.65,16.5 \mathrm{mmol} \cdot \mathrm{dm}^{-3}$ (標準濃度 $1.65 \mathrm{mg} \cdot \mathrm{dm}^{-3}$ ) 添加し た. ゼラチン, チオ尿素, 塩化物イオンの上記の標準条件の 濃度は, 日本の主要銅電解工場の一例を参考にして設定した. 陰極, 陽極には片面をエポキシ系樹脂で絶縁被覆した $\mathrm{Cu}$ 板 (陰極 $3 \mathrm{~cm} \times 3 \mathrm{~cm}$, 陽極 $6 \mathrm{~cm} \times 7 \mathrm{~cm}$ ) を用い, 浴温 $60^{\circ} \mathrm{C}$, 無 攪拌にて $200 \mathrm{~A} \cdot \mathrm{m}^{-2}$, 通電量 $500 \times 10^{3} \mathrm{C} \cdot \mathrm{m}^{-2}$ で定電流電解を 行った. ゼラチンは, 電解液に添加後, 徐々に分解すること 
Table 1 Electrolysis conditions.

\begin{tabular}{lll}
\hline & $\mathrm{CuSO}_{5} \cdot 5 \mathrm{H}_{2} \mathrm{O}\left(\mathrm{mol}^{-3} \mathrm{dm}^{-3}\right)$ & 0.708 \\
Bath composition & $\cdot \mathrm{H}_{2} \mathrm{SO}_{4}\left(\mathrm{~mol} \cdot \mathrm{dm}^{-3}\right)$ & 2.04 \\
& $\cdot$ Gelatin $\left(\mathrm{mg} \cdot \mathrm{dm}^{-3}\right) 0.171(\times 1 / 10), 1.71(\times 1), 17.1(\times 10)$ \\
& $\cdot$ Thiourea $\left(\mathrm{mmol}^{-3} \mathrm{dm}^{-3}\right) 0.0023(\times 1 / 10), 0.023(\times 1), 0.23(\times 10), 2.3(\times 100)$ \\
& $\cdot \mathrm{Cl}^{-}\left(\mathrm{mmol} \cdot \mathrm{dm}^{-3}\right) 0.165(\times 1 / 10), 1.65(\times 1), 16.5(\times 10)$ \\
\hline & Anode current density $\left(\mathrm{A} \cdot \mathrm{m}^{-2}\right) \quad 200$ \\
& $\cdot$ Temperature $\left({ }^{\circ} \mathrm{C}\right)$ & 60 \\
Operating conditions & $\cdot$ Cathode $\quad \mathrm{Cu}(3 \mathrm{~cm} \times 3 \mathrm{~cm})$ \\
& $\cdot$ Anode $\quad \mathrm{Cu}(6 \mathrm{~cm} \times 7 \mathrm{~cm})$ \\
& $\cdot$ Amount of charge $\left(\mathrm{C} \cdot \mathrm{m}^{-2}\right) \quad 5 \times 10^{5}$ \\
& $\cdot$ No stirring \\
\hline
\end{tabular}

$\times 1$ : standard concentration, $\times 1 / 10$ : one tenth of standard, $\times 10$ : ten times of standard

$\mathrm{x} 1 / 10$

(a)

Gelatin
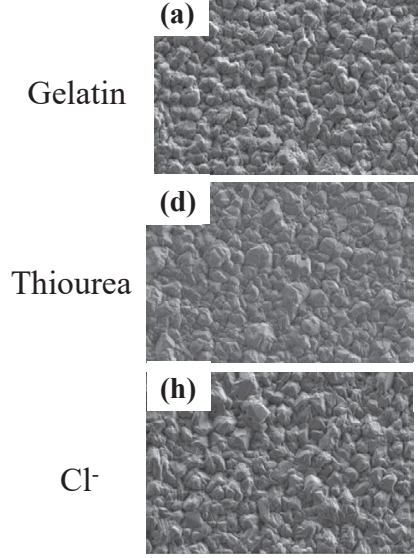

$\mathrm{Cl}^{-}$

(k) $\mathrm{x} 1$
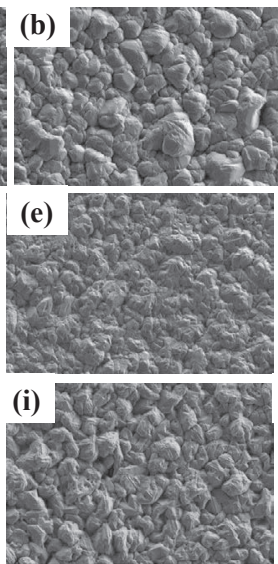

$\mathrm{x} 10$
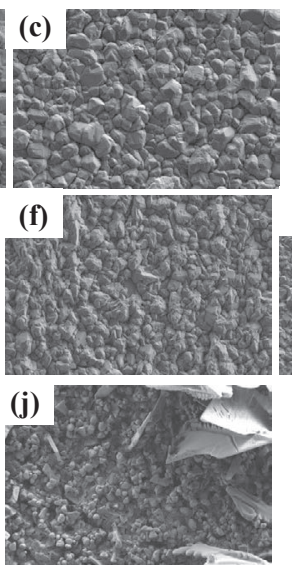

$\mathrm{x} 100$

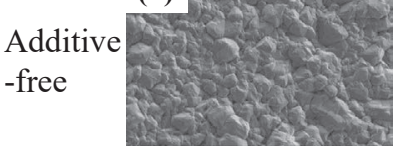

$10 \underline{\mu m}$

Fig. 1 Surface SEM images of $\mathrm{Cu}$ electrodeposited from the solutions containing various single additives of (a-c) gelatin of (a) 0.171 , (b) 1.71 and $(\mathrm{c}) 17.1 \mathrm{mg} \cdot \mathrm{dm}^{-3}$, (d-g) thiourea of (d) 0.0023 , (e) 0.023 , (f) 0.23 and (g) $2.3 \mathrm{mmol} \cdot \mathrm{dm}^{-3}$, (h-j) $\mathrm{Cl}^{-}$of (h) 0.165 , (i) 1.65 and (j) $16.5 \mathrm{mmol} \cdot \mathrm{dm}^{-3}$, and $(\mathrm{k})$ without any additives as reference.

が予想されるため, 添加後, 直ぐに電解実験を行った，分極 曲線を作成する際の陰極電位は, 参照電極として $\mathrm{Ag} / \mathrm{AgCl}$ 電 極(飽和 $\mathrm{KCl}, 0.199 \mathrm{~V}$ vs. NHE， $25^{\circ} \mathrm{C}$ )を用いて， $1 \sim 2000$ $\mathrm{A} \cdot \mathrm{m}^{-2}$ の各電流密度で 3 分間電解後に測定し, 標準水素電極 基準に換算して表示した。

得られた電析 $\mathrm{Cu}$ の表面中央部を SEMにて観察し，一部の 供試材については，元素分布をEPMAにより調べた，電析 $\mathrm{Cu}$ の中央部の表面粗度 Ra を表面粗さ形状測定機(東京精密 (株)製 SURFCOM1500DX-3DF)により測定した。表面粗度 $\mathrm{Ra}$ は, 測定長さ $10 \mathrm{~mm}$, 測定速度 $0.15 \mathrm{~mm} \cdot \mathrm{s}^{-1}$, カットオフ 波長 $0.25 \mathrm{~mm}$ の条件にて測定し, JIS 規格に基づき算出した. 電析 $\mathrm{Cu}$ の均一電着性は, $\mathrm{Cu}$ の膜厚曲線より評価した。

電析 $\mathrm{Cu}$ の膜厚は, 上記の表面粗さ形状測定機により, 試 料のエッジからエッジまで(測定長さ $30 \mathrm{~mm}$ ), 測定速度 3.0 $\mathrm{mm} \cdot \mathrm{s}^{-1}$, カットオフ波長 $0.08 \mathrm{~mm}$ の条件にて電析 $\mathrm{Cu}$ の高さ を測定し, 電析前の高さとの差より算出した. 得られた膜厚 曲線の板幅方向に扔ける傾斜が $0.3 \mu \mathrm{m} \cdot \mathrm{mm}^{-1}$ となる領域を平 坦部と定義し, 平坦部の長さで均一電着性を評価した。

\section{3. 結果および考察}

\section{1 電析 $\mathrm{Cu}$ の表面形態に及ぼす添加剤の影響}

Fig. 1 にゼラチン, チオ尿素, 塩化物イオンを単独で添加 した溶液から電析させた $\mathrm{Cu}$ の表面 SEM 像を示す. 添加剂を 含まない溶液 $(\mathrm{k})$ から得られた $\mathrm{Cu}$ は, $10 \mu \mathrm{m}$ 前後の塊状の結 晶から構成された。電析 $\mathrm{Cu}$ の結晶粒は，ゼラチンを 0.171 $\mathrm{mg} \cdot \mathrm{dm}^{-3}$ 添加すると (a), 無添加の場合に比べて若干小さくな るが, 添加量を標準濃度の $1.71 \mathrm{mg} \cdot \mathrm{dm}^{-3}$ に増加すると(b) 逆

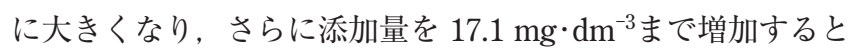
(c)また小さくなった. チ才尿素の単独添加については, その 添加濃度が高くなるほど $[(\mathrm{d}),(\mathrm{e}),(\mathrm{f}),(\mathrm{g})]$, 電析 $\mathrm{Cu} の$ 結晶粒は小さくなった，一方，塩化物イオンを添加すると， その添加量 $0.165,1.65 \mathrm{mmol} \cdot \mathrm{dm}^{-3}[(\mathrm{~h}),(\mathrm{i})]$ では, 電析 $\mathrm{Cu}$ の塊状結晶の凹凸が無添加の場合に比べてょり明暸となった。 また, 添加量を標準濃度の $1.65 \mathrm{mmol} \cdot \mathrm{dm}^{-3}(\mathrm{i})$ にした場合, 塊状結晶の表面が平滑でなく平板の積層が認められた，塩化 物イオンの添加量を標準濃度の10倍である $16.5 \mathrm{mmol} \cdot \mathrm{dm}^{-3}$ ま で増加させると $(\mathrm{j})$, 電析 $\mathrm{Cu}$ の形態は大きく変化し, 微細な 
粒と大きな板状の結晶から構成された。この微細な粒と大き な板状の結晶の成分を次に EPMAにて調査した.

Fig. 2 に塩化物イオンを単独で $16.5 \mathrm{mmol} \cdot \mathrm{dm}^{-3}$ 添加した溶 液から電析させた $\mathrm{Cu}$ の表面 EPMA 像を示す。電析 $\mathrm{Cu}$ の微 細な粒状結晶 (a)の箇所 (図中の $\square$ 内)において, 元素分析を 行ったところ，（b)に示すように $\mathrm{Cu}$ 成分の他に $\mathrm{CuCl}$ の成分 が検出された．塩化物イオンを含む電解液での $\mathrm{Cu}$ 電析は，一 価 $\mathrm{Cu}$ の $\mathrm{CuCl}$ を経由して生じることが報告されており ${ }^{16)}$, $\mathrm{CuCl}$ の析出物は鱗片状および微細な粒状となることが示され ている ${ }^{16)}$. 本研究において, 塩化物イオンを $16.5 \mathrm{mmol} \cdot \mathrm{dm}^{-3}$ と標準濃度の 10 倍の濃度で添加すると, 電析物に $\mathrm{CuCl}$ の成 分が検出されたのは, 反応中間体である $\mathrm{CuCl}$ が多量に形成 され，電析物に巻き込まれたため考えられる，そこで，以下 の実験では, 塩化物イオンの添加量は, $0.165,1.65 \mathrm{mmol}$ • $\mathrm{dm}^{-3}$ とした.

Fig. 3 にゼラチン, チオ尿素, 塩化物イオンの 3 種類を 種々の濃度となるように添加した溶液から電析させた $\mathrm{Cu}$ の 表面 SEM 像を示す. ゼラチン $1.71 \mathrm{mg} \cdot \mathrm{dm}^{-3}$, チ才尿素 0.023 $\mathrm{mg} \cdot \mathrm{dm}^{-3}$, 塩化物イオン $1.65 \mathrm{mg} \cdot \mathrm{dm}^{-3}$ を標準濃度として各々 の添加量を変化させた。 ゼラチンはその濃度を高くする程, 電析 $\mathrm{Cu}$ の結晶粒は小さくなった $[(\mathrm{b}),(\mathrm{c}),(\mathrm{d})]$. Fig. 1 に 示すように, ゼラチン単独添加の場合は, $0.171 \mathrm{mg} \cdot \mathrm{dm}^{-3}$ 添加 に比べ $1.71 \mathrm{mg} \cdot \mathrm{dm}^{-3}$ 添加の方が, 電析 $\mathrm{Cu}$ の結晶粒は大きく なっており，3 種類添加の場合は, ゼラチン単独添加とは傾 向が若干異なった. チオ尿素の添加についても, ゼラチン添
加と同様に, その濃度を高くする程, 電析 $\mathrm{Cu}$ の結晶粒は小 さくなった $[(\mathrm{e}),(\mathrm{c}),(\mathrm{f}),(\mathrm{g})]$. この傾向は, チ才尿素の 単独添加の場合と同様であった。一方, 塩化物イオンの添加 については, その添加量を標準濃度 $\left(1.65 \mathrm{mmol} \cdot \mathrm{dm}^{-3}\right)$ から $0.165 \mathrm{mmol} \cdot \mathrm{dm}^{-3}$ に低下した方 $(\mathrm{h})$ が電析 $\mathrm{Cu}$ の結晶粒は明ら かに小さくなり, 表面が平滑となった.

\section{2 電析 $\mathrm{Cu}$ の表面粗度, 均一電着性に及ぼす添加剂の影響}

Fig. 4 にゼラチン, チオ尿素, 塩化物イオンを単独で添加 した溶液から電析させた $\mathrm{Cu}$ の表面粗度を示す. チオ尿素を 添加した場合, 標準濃度の $0.023 \mathrm{mg} \cdot \mathrm{dm}^{-3}$ までは, 電析 $\mathrm{Cu} の$ 表面粗度は, 無添加の場合とほほ同一であったが, 添加量が $0.23,2.3 \mathrm{mg} \cdot \mathrm{dm}^{-3}$ と多くなると, 粗度は大きく低下した. 塩 化物イオンの添加については, 標準濃度の1/10である 0.165 $\mathrm{mmol} \cdot \mathrm{dm}^{-3}$ の添加で無添加の場合に比べ粗度は大きくなり,

$1.65 \mathrm{mmol} \cdot \mathrm{dm}^{-3}$ の添加で粗度はさらに大きくなった。 このよ うに, 塩化物イオンには, 明らかに電析 $\mathrm{Cu}$ の表面粗度を大 きくする作用が認められた。一方, ゼラチンの添加において は, 標準濃度の $1 / 10$ である $0.171 \mathrm{mg} \cdot \mathrm{dm}^{-3}$ の添加では, 電析 $\mathrm{Cu}$ の表面粗度は無添加の場合とほぼ同一であるが, $1.71 \mathrm{mg}$. $\mathrm{dm}^{-3}$ の添加では, やや大きくなり, $17.1 \mathrm{mg} \cdot \mathrm{dm}^{-3}$ の添加では, 逆に小さくなった. ゼラチン単独添加の表面粗度は, Fig. 1 に示す表面形態の傾向とほぼ一致した.

Fig. 5 にゼラチン, チオ尿素, 塩化物イオンの 3 種類を 種々の濃度となるように添加した溶液から電析させた $\mathrm{Cu}$ の
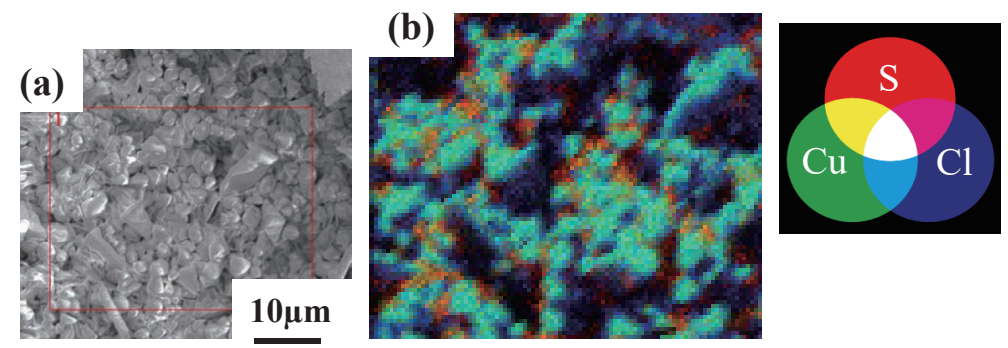

Fig. 2 EPMA images of surface of $\mathrm{Cu}$ deposited from the solution containing $16.5 \mathrm{mmol} \cdot \mathrm{dm}^{-3}$ of $\mathrm{Cl}^{-}$ions. [(a) SE image, (b) mapping of (a)]

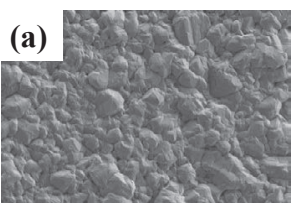

(e)

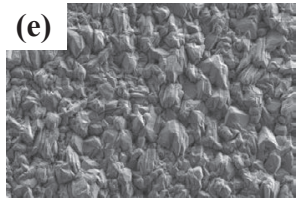

(b)
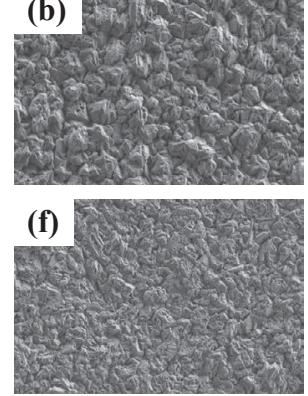

(c)

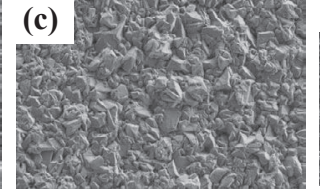

(g)

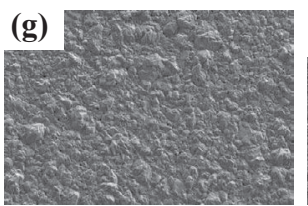

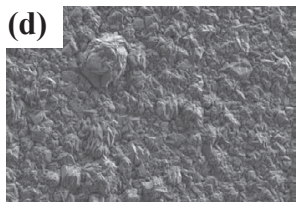

(h)

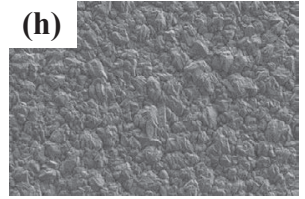

$10 \mu \mathrm{m}$

\begin{tabular}{|c|c|c|c|c|c|c|c|}
\hline & (a) & (b) & (c) & (d) & (e) & (g) & (h) \\
\hline Gelatin $\left(\mathrm{mg} \cdot \mathrm{dm}^{-3}\right)$ & 0 & $0.171(\mathrm{x} 1 / 10)$ & $1.71(\mathrm{x} 1)$ & $17.1(\mathrm{x} 10)$ & $1.71(\mathrm{x} 1)$ & & \\
\hline Thiourea $\left(\mathrm{mmol} \cdot \mathrm{dm}^{-3}\right)$ & 0 & 0.02 & $23(\mathrm{x} 1)$ & & \begin{tabular}{|l|l|}
$0.0023(\mathrm{x} 1 / 10)$ & $0.23(\mathrm{x} 10)$ \\
\end{tabular} & $2.3(\mathrm{x} 100)$ & $0.023(\mathrm{x} 1)$ \\
\hline $\mathrm{Cl}^{-}\left(\mathrm{mmol} \cdot \mathrm{dm}^{-3}\right)$ & 0 & & & & $5(\mathrm{x} 1)$ & & $0.165(\mathrm{x} 1 / 10)$ \\
\hline
\end{tabular}

Fig. 3 Surface SEM images of $\mathrm{Cu}$ deposited from the solutions containing three kinds of additives. 


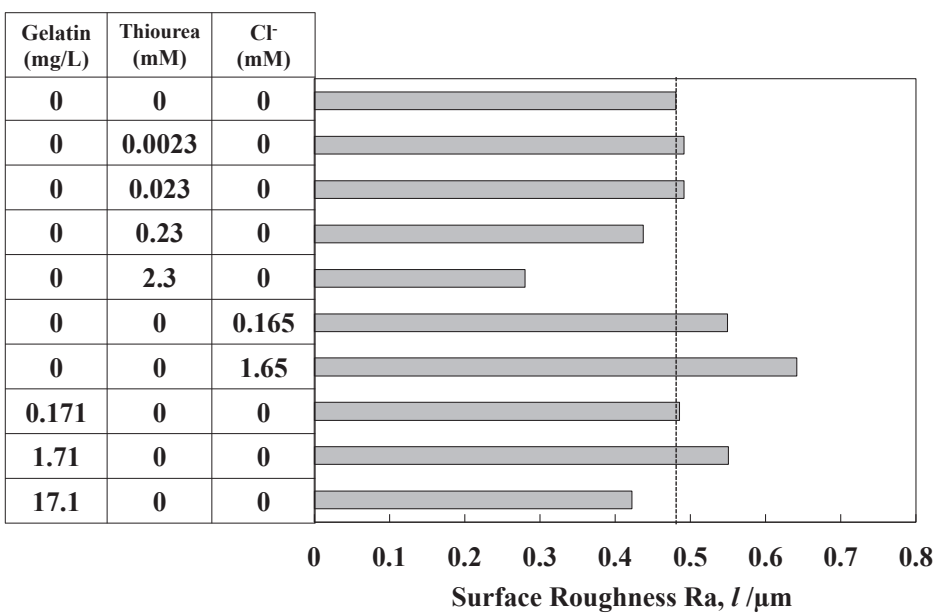

Fig. 4 Surface roughness of $\mathrm{Cu}$ deposited from the solutions containing single additive.

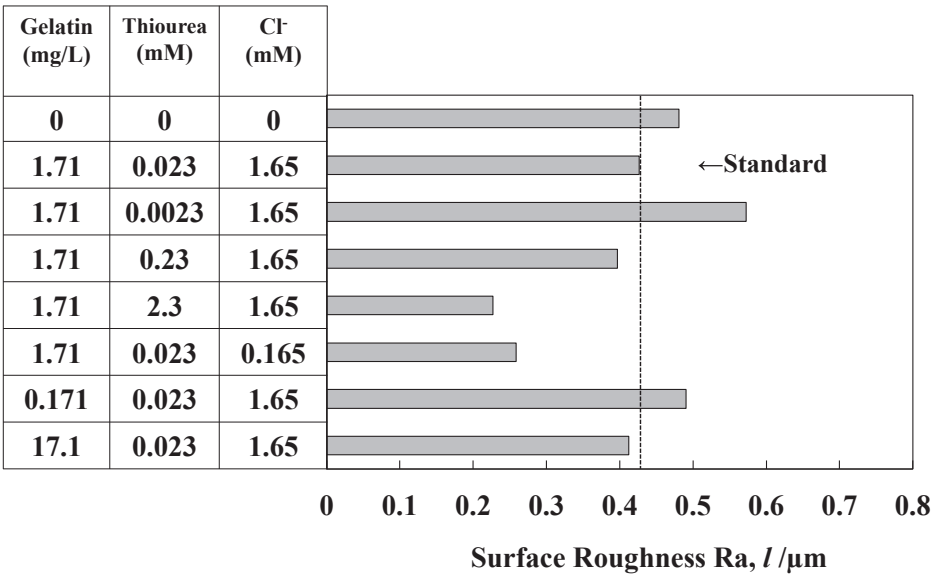

Fig. 5 Surface roughness of $\mathrm{Cu}$ deposited from the solutions containing three kinds of additives.

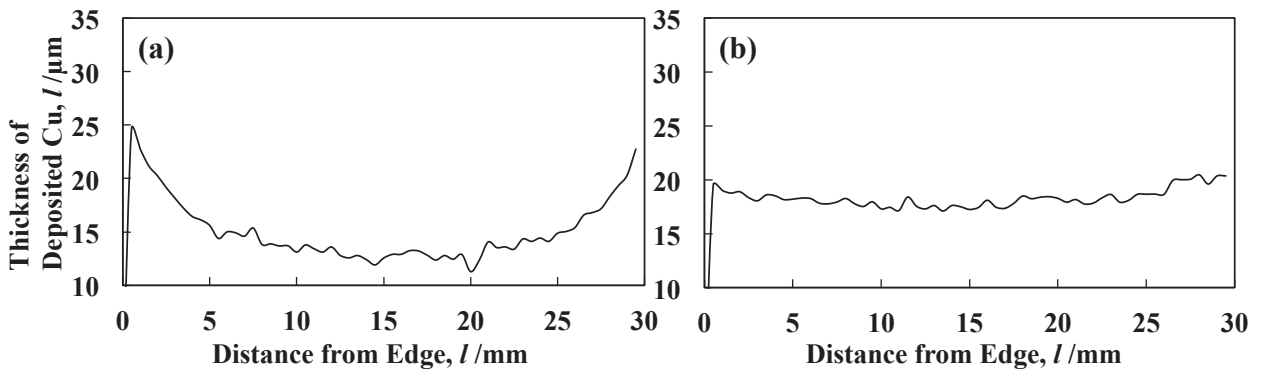

Fig. 6 Thickness profiles of $\mathrm{Cu}$ deposited from solutions without and with three kinds of additives. [(a) Additive-free, (b) Gelatin 1.71 $\mathrm{mg} \cdot \mathrm{dm}^{-3}$, Thiurea $\left.0.023 \mathrm{mmol} \cdot \mathrm{dm}^{-3}, \mathrm{Cl}^{-} 1.65 \mathrm{mmol} \cdot \mathrm{dm}^{-3}\right]$

表面粗度を示す。 3 種類を標準濃度で添加すると， 電析 $\mathrm{Cu}$ の表面粗度は，添加剤を含まない溶液からのものに比べて明 らかに低下した。しかし，チ才尿素の濃度を $0.0023 \mathrm{mmol}$ ・ $\mathrm{dm}^{-3}$ に低下させると粗度は, 添加剤なしの場合より高くなっ た.これは, チオ尿素の濃度が低くなると, 塩化物イオンに よる粗度増加の作用を打ち消すことができないことを示して いる. チ才尿素の濃度を $0.23,2.3 \mathrm{mmol} \cdot \mathrm{dm}^{-3}$ と増加させる と，表面粗度は大きく低下した。 また，塩化物イオンの濃度 を標準濃度の $1 / 10$ である $0.165 \mathrm{mmol} \cdot \mathrm{dm}^{-3}$ に低下させると, 粗度は大きく低下した。これは，Fig. 3 に示す表面形態の結 果とも対応している. 一方, ゼラチンの添加については, 添
加量を $0.171 \mathrm{mg} \cdot \mathrm{dm}^{-3}$ に低下させると, 電析 $\mathrm{Cu}$ の表面粗度は 増加し, 添加量を $17.1 \mathrm{mg} \cdot \mathrm{dm}^{-3}$ に増加させると粗度は低下し た.すなわち， 3 種類の添加剤共存下では，ゼラチンはその 濃度が高くなる程, 粗度は小さくなった。

次に, 電析 $\mathrm{Cu}$ の均一電着性に及ぼす添加剤の相乗効果を $\mathrm{Cu}$ の膜厚曲線より評価した. Fig. 6 は, 添加剤なしおよび標 準濃度の 3 種類の添加剂を含む溶液から得られた $\mathrm{Cu}$ の膜厚 曲線を示す。添加剤を含まない溶液から得られた $\mathrm{Cu}$ の膜厚 (a) は, エッジ部で厚く, 中央部で薄くなっているのに対し て， 3 種類の添加剤を含む溶液から得られた $\mathrm{Cu}$ の膜厚 $(\mathrm{b})$ は, エッジ部で若干厚くなっているものの, 添加剤なしの場合に 
比べて均一になっていることが分かる，本研究では，この膜 厚曲線の板幅方向における傾斜が $0.3 \mu \mathrm{m} \cdot \mathrm{mm}^{-1}$ 以下となる領 域を平坦部と定義し, 以後, この平坦部の長さにより均一電 着性を評価した。

Fig. 7 にゼラチン, チオ尿素, 塩化物イオンを単独で添加 した溶液から電析させた $\mathrm{Cu}$ の均一電着性を示す。塩化物イ オンを添加するとその濃度が高くなるほど, $\mathrm{Cu}$ の均一電着性 は明らかに向上した．塩化物イオンは，Fig. 4，5に示す様に 表面の粗度は粗くしたが均一電着性は改善した。ゼラチン添 加の場合も $\mathrm{Cu}$ の均一電着性は改善されたが, その効果は標 準濃度の10倍の $17.1 \mathrm{mg} \cdot \mathrm{dm}^{-3}$ に増加させた時に塩化物イオン の標準濃度 $\left(1.65 \mathrm{mmol} \cdot \mathrm{dm}^{-3}\right)$ 並みとなった. チ才尿素も単独 添加の場合は, 無添加の場合に比べて均一電着性を若干向上
させた.

Fig. 8 にゼラチン, チオ尿素, 塩化物イオンの中から 2 種 類を各々の標準濃度となるように添加した溶液から電析させ た $\mathrm{Cu}$ の均一電着性を示す。いずれの添加剤を加えた場合も, $\mathrm{Cu}$ の均一電着性は向上したが, ゼラチンと塩化物イオンを添 加した場合がその効果は最も顕著であった．ゼラチンと塩化 物イオンの改善効果は, 3 種類全てを添加した場合と同等で あった。

Fig. 9 にゼラチン, チオ尿素, 塩化物イオンの 3 種類を 種々の濃度となるように添加した溶液から電析させた $\mathrm{Cu}$ の 均一電着性を示す。 3 種類をそれぞれ標準濃度となるように 添加した場合, 無添加の場合に比べて, 均一電着性は大きく 改善された. 3 種類の添加鼡の標準濃度での添加に比べて,

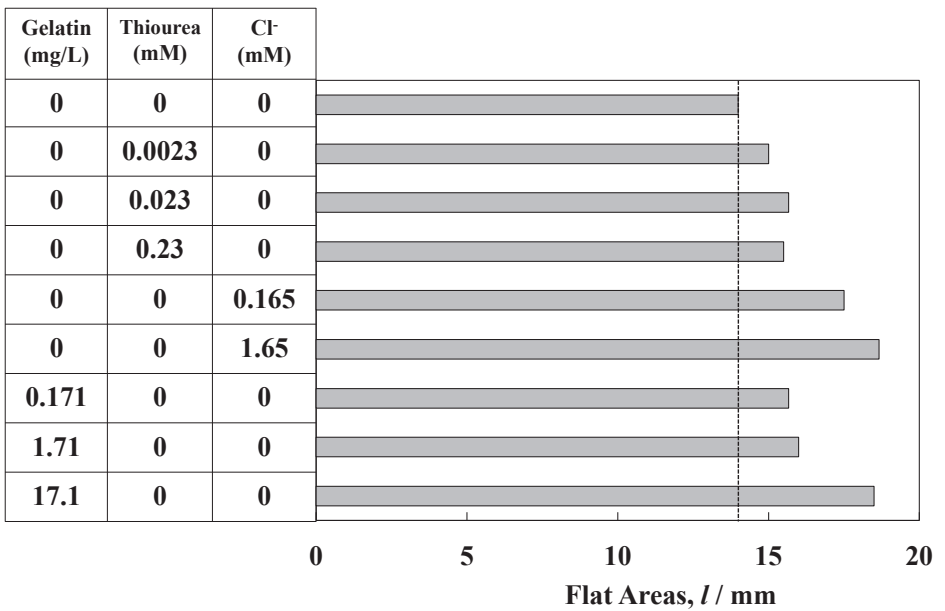

Fig. 7 Throwing power of $\mathrm{Cu}$ deposited from the solutions containing single additive.

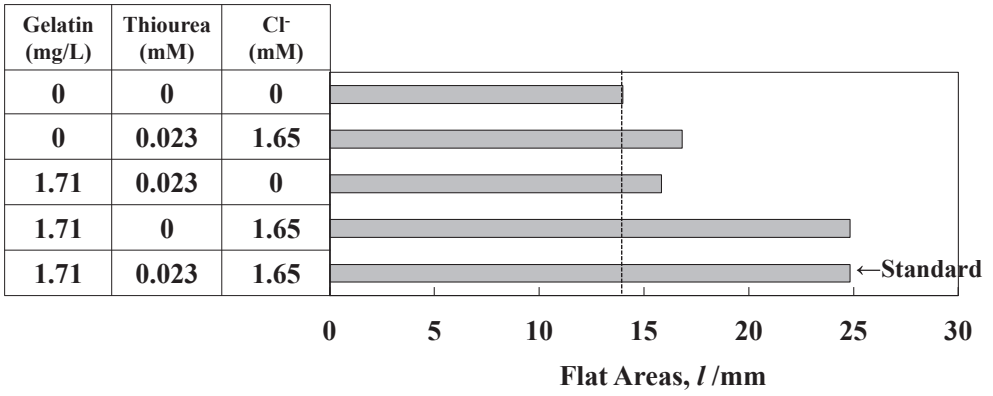

Fig. 8 Throwing power of $\mathrm{Cu}$ deposited from the solutions containing two kinds of additives.

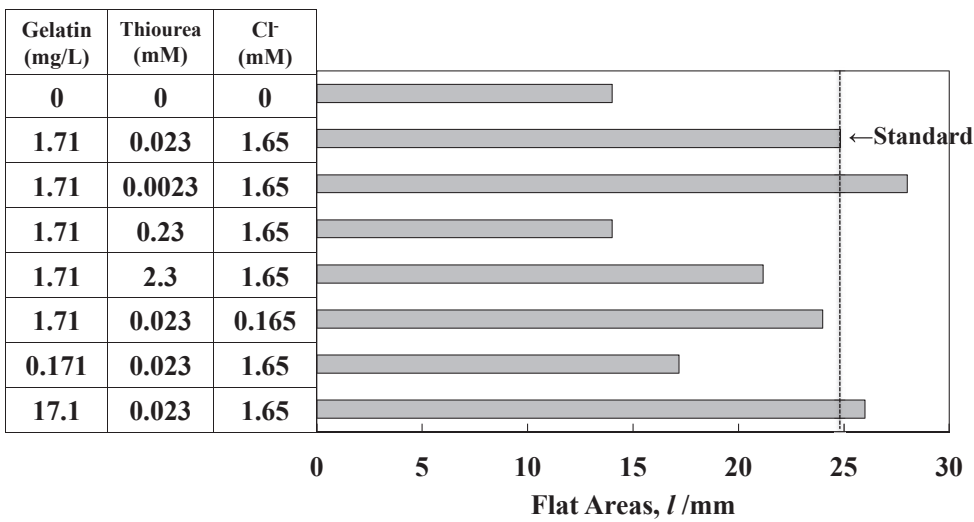

Fig. 9 Throwing power of $\mathrm{Cu}$ deposited from the solutions containing three kinds of additives. 
チオ尿素の濃度を $0.0023 \mathrm{mmol} \cdot \mathrm{dm}^{-3}$ に低下させると均一電着 性はより向上した。しかし，チ才尿素の濃度を $0.23,2.3$ $\mathrm{mmol} \cdot \mathrm{dm}^{-3}$ に増加させると, 均一電着性は, 標準濃度での添 加に比べて悪くなった. チオ尿素単独添加の場合はその濃度 にかかわらず, 無添加の場合より, 均一電着性は若干改善さ れたが, ゼラチン, チオ尿素, 塩化物イオンの 3 種類添加の 場合は, 均一電着性は, チオ尿素の濃度に大きく依存し, 単 独添加の場合とは異なる傾向を示した. 塩化物イオンは, そ の濃度を $0.165 \mathrm{mmol} \cdot \mathrm{dm}^{-3}$ に低下させると, 均一電着性は若 干劣化した. 一方, ゼラチンは, その濃度を $0.171 \mathrm{mg} \cdot \mathrm{dm}^{-3}$ に低下させると, 均一電着性は大きく低下し, $17.1 \mathrm{mg} \cdot \mathrm{dm}^{-3}$ と高くすると, 若干改善された.

\section{$3.3 \mathrm{Cu}$ 電析の分極曲線による添加剂の効果の考察}

電析 $\mathrm{Cu}$ の表面粗度, 均一電着性に及ぼす添加剤の相乗効 果の要因を考察するために $\mathrm{Cu}$ 電析の分極曲線に及ぼす添加 剂の影響を調査した. Fig. 10 にゼラチン, チオ尿素, 塩化物 イオンをそれぞれの標準濃度となるように単独で添加した溶 液から得られた $\mathrm{Cu}$ 電析の分極曲線を示す. $0.3 \mathrm{~V}, 200 \mathrm{~A} / \mathrm{m}^{2}$ 近傍の分極曲線を拡大して [Fig. 10(b) ], 100 $200 \mathrm{~A} / \mathrm{m}^{2}$ の電 流密度領域での電位に着目すると, いずれの添加剤において も僅かではあるが $\mathrm{Cu}$ 電析に対する分極効果が見られた。し かし, 電流密度が $200 \mathrm{~A} / \mathrm{m}^{2}$ を超えて高くなると, チ才尿素に は復極効果が認められ, $\mathrm{Cu}$ 電析を促進することが分かる. $200 \mathrm{~A} / \mathrm{m}^{2}$ においても, 分極抵抗 (分極曲線の勾配 $\mathrm{d} E / \mathrm{d} i$ ) は, チオ尿素を添加すると, 無添加の場合に比べて小さくなった.

Fig. 11 にチオ尿素を種々の濃度なるように単独で添加した
溶液から得られた $\mathrm{Cu}$ 電析の分極曲線を示す. 分極曲線 $[\mathrm{Fig}$. 11 (b)]は, チ才尿素の濃度が $0.23,2.3 \mathrm{mmol} \cdot \mathrm{dm}^{-3}$ と高くな ると, 明らかに分極したが, 濃度が $0.023,0.0023 \mathrm{mmol}$. $\mathrm{dm}^{-3}$ と低くなると, $200 \mathrm{~A} / \mathrm{m}^{2}$ 以上では復極した. $200 \mathrm{~A} / \mathrm{m}^{2}$ に おいても, 濃度が $0.023,0.0023 \mathrm{mmol} \cdot \mathrm{dm}^{-3}$ の場合, 分極抵抗 $\mathrm{d} E / \mathrm{d} i$ は, 無添加の場合に比べて小さくなっており, この低 濃度の領域では, チオ尿素は $\mathrm{Cu}$ 電析を促進することが分か る.

Fig. 12 にゼラチンを種々の濃度なるように単独で添加した 溶液から得られた $\mathrm{Cu}$ 電析の分極曲線を示す。 $0.3 \mathrm{~V}, 200 \mathrm{~A} / \mathrm{m}^{2}$ 近傍を拡大した分極曲線 Fig. 12(b)より分かるように，ゼラ チンの単独添加では, 添加量を $17.1 \mathrm{mg} \cdot \mathrm{dm}^{-3}$ と多くした場合

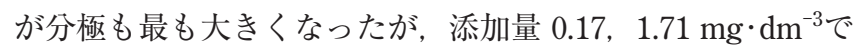

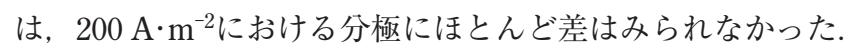
ゼラチンの単独添加において, 添加量を $17.1 \mathrm{mg} \cdot \mathrm{dm}^{-3}$ と多く した時, 表面粗度が小さくなり (Fig. 4), また均一電着性は改 善されており (Fig. 7), これは, 分極が大きいことと対応して いる.

Fig. 13 に塩化物イオンを単独添加した溶液から得られた $\mathrm{Cu}$ 電析の分極曲線を示す. $0.3 \mathrm{~V}, 200 \mathrm{~A} / \mathrm{m}^{2}$ 近傍を拡大した分極 曲線 Fig. 13(b)より, 塩化物イオンを1.65, $0.165 \mathrm{mmol} \cdot \mathrm{dm}^{-3}$ 添加すると, $\mathrm{Cu}$ 電析は分極することが分る. 微量の塩化物イ オンを含む溶液からの $\mathrm{Cu}$ 電析は, 回転リング・ディスク電 極法により, $\mathrm{Cu}^{+}$の吸着中間体 $\mathrm{CuCl}_{\mathrm{ad}}$ を経由して進行するこ とが報告されており ${ }^{16)}$, この $\mathrm{CuCl}$ から $\mathrm{Cu} へ の$ 還元の平衡電 位が $\mathrm{Cu}^{2+}$ から $\mathrm{Cu} へ の$ 平衡電位に比べて卑である.このため, $\mathrm{Cu}$ 電析は, 塩化物イオンの添加により分極したと考えられ
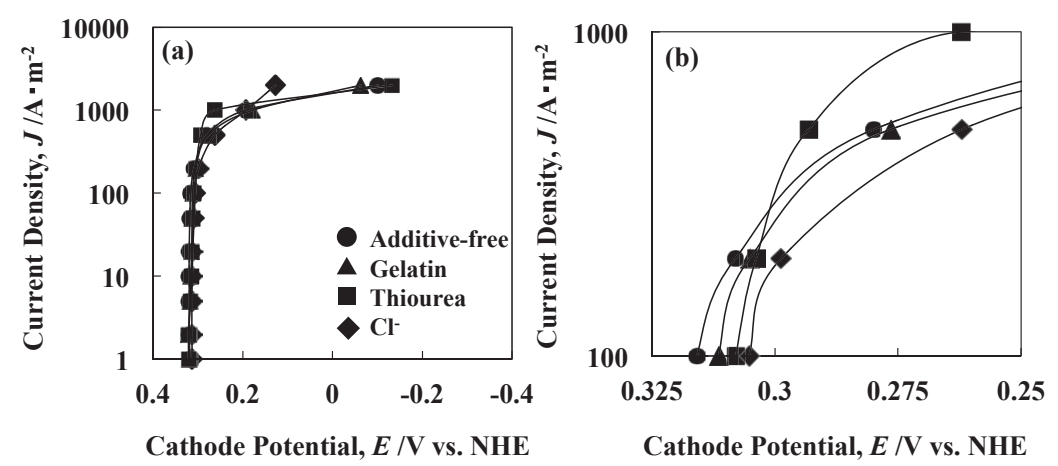

Fig. 10 Polarization curves for $\mathrm{Cu}$ deposition from the solutions containing single additive. [Gelatin $1.71 \mathrm{mg} \cdot \mathrm{dm}^{-3}$, Thiourea 0.023 $\mathrm{mmol} \cdot \mathrm{dm}^{-3}, \mathrm{Cl}^{-} 1.65 \mathrm{mmol} \cdot \mathrm{dm}^{-3}$, (a) Normal, (b) Magnification]
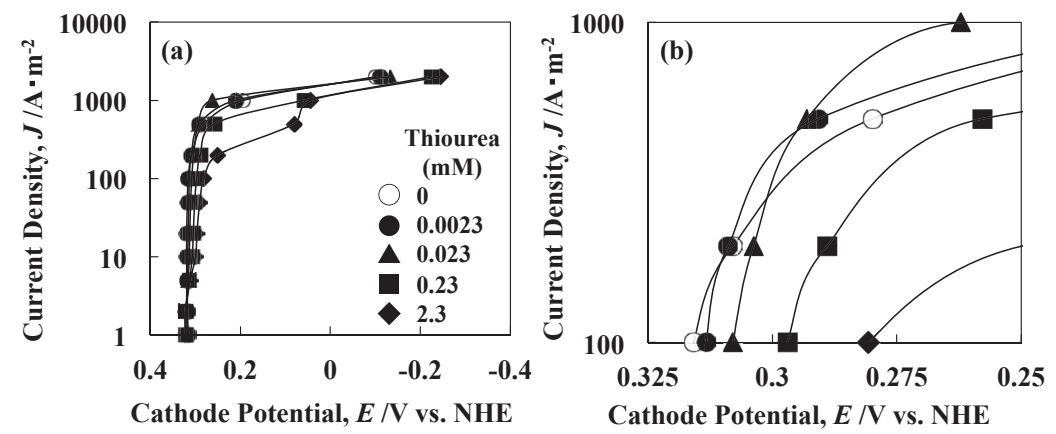

Fig. 11 Polarization curves for $\mathrm{Cu}$ deposition from the solutions containing various amounts of thiourea as single additive. [(a) Normal, (b) Magnification] 

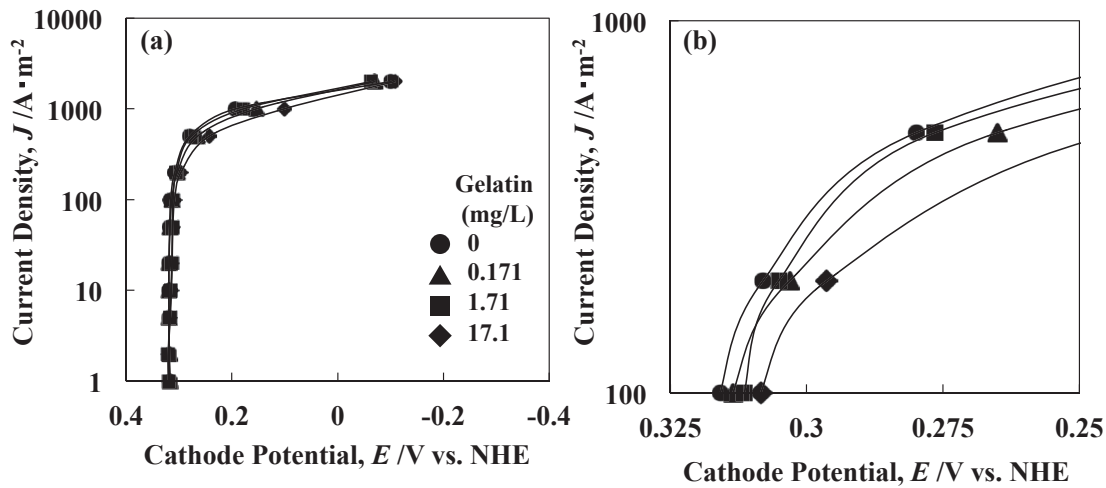

Fig. 12 Polarization curves for $\mathrm{Cu}$ deposition from the solutions containing various amounts of gelatin as single additive. [(a) Normal, (b) Magnification]
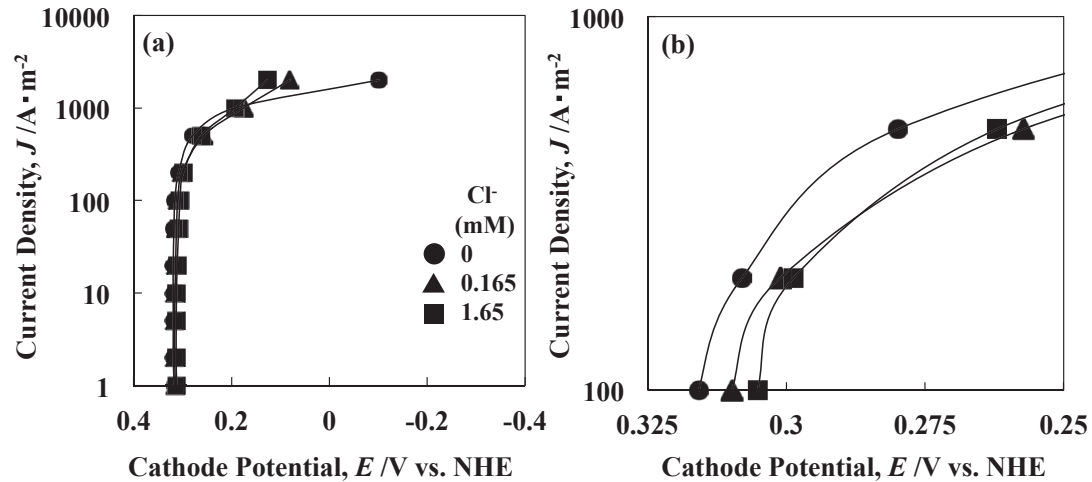

Fig. 13 Polarization curves for $\mathrm{Cu}$ deposition from the solutions containing various amounts of chloride ions as single additive. [(a) Normal, (b) Magnification]
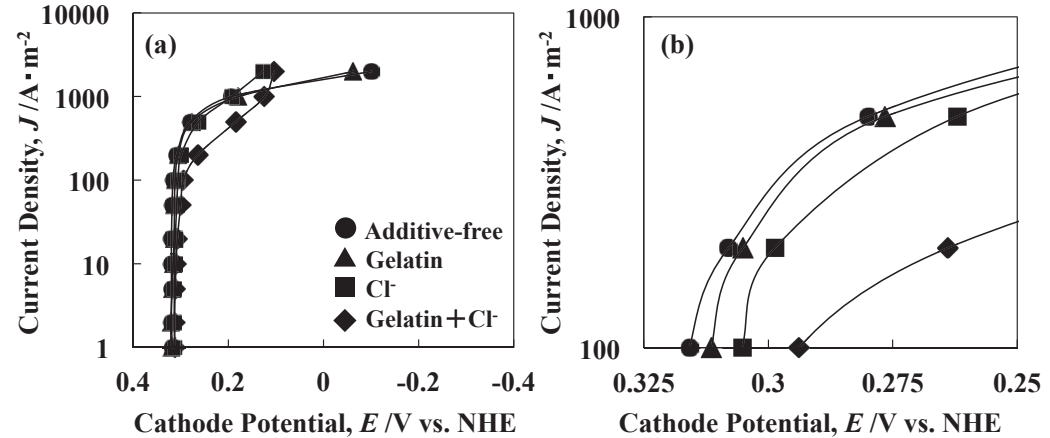

Fig. 14 Polarization curves for $\mathrm{Cu}$ deposition from the solution containing both gelatin and chloride ions. [Gelatin $1.71 \mathrm{mg} \cdot \mathrm{dm}^{-3}, \mathrm{Cl}^{-}$ $1.65 \mathrm{mmol} \cdot \mathrm{dm}^{-3}$, (a) Normal, (b) Magnification]

る.

Fig. 14 にゼラチンと塩化物イオンを含む溶液から得られた $\mathrm{Cu}$ 電析の分極曲線を示す． $\mathrm{Cu}$ 電析は，ゼラチンの単独添加 ではほとんど分極しなかったが, 塩化物イオンが共存すると 大きく分極しており，ゼラチンと塩化物イオンの相乗効果が 見られた. 上述したように, $\mathrm{Cu}$ 電析は, 微量の塩化物イオン を含む溶液では, 中間生成物の $\mathrm{CuCl}$ を経由して進行する16). ポリエチレングリコールのような直鎖状高分子の添加剤は, $\mathrm{Cu}^{+}$の吸着中間体 $\mathrm{CuCl}_{\mathrm{ad}}$ から金属 $\mathrm{Cu}$ への還元反応を抑制す ることが交流インピーダンス法による解析結果から実証され ている16). ゼラチンもポリエチレングリコールと同様に直鎖 状の高分子であり，中間生成物の $\mathrm{CuCl}$ から金属 $\mathrm{Cu}$ への還元 反応を抑制することが考えられる。このため, $\mathrm{Cu}$ 電析の分極
に対するゼラチンと塩化物イオンの相乗効果が出現したと推 察される.

電析物の均一電着性は, 電解槽における電流分布により決 まる，不均一電流分布のモデル計算より，電流密度分布は， 電析反応の分極抵抗 $\mathrm{d} E / \mathrm{d} i$ に大きく依存し，分極抵抗が大き くなる程，均一になることが報告されている ${ }^{21,22)}$. 本研究に おいて, Fig. 8 に示すように，ゼラチンと塩化物イオンを添 加すると均一電着性が向上したのは，分極抵抗 $\mathrm{d} E / \mathrm{d} i$ が大き くなったためと考えられる。 また，微量添加のチ才尿素には， 銅電析に対する復極作用があり (Fig. 11), 電析物の凹部での 電析促進による平滑化効果が期待される。 ゼラチン，チ才尿 素, 塩化物イオンの 3 種類添加において, チオ尿素の濃度を $0.23,2.3 \mathrm{mmol} \cdot \mathrm{dm}^{-3}$ と増加させると, 均一電着性が標準濃度 
で添加した場合に比べて悪くなったのは (Fig. 9), チオ尿素の 濃度増加により銅電析に対するその復極作用が消失するため と推察される.

\section{4. 結言}

電解精製浴からの電析 $\mathrm{Cu}$ の表面形態, 表面粗度, 均一電 着性, 分極曲線に及ぼすゼラチン, チオ尿素, 塩化物イオン の影響について調査した結果，以下のことが分かった.

(1) 電析 $\mathrm{Cu}$ の表面粗度は， 3 種類の添加剂を含む溶液に おいて, チオ尿素の濃度が増加する程, 塩化物イオンの濃度 が低下する程，またゼラチンの濃度が増加する程，低下した.

(2) 電析 $\mathrm{Cu}$ の均一電着性は, 3 種類を添加した溶液にお いて, チ才尿素の濃度を低下させ, ゼラチンの濃度を増加さ せると向上した。また, 均一電着性は, ゼラチンと塩化物イ オンが共存すると大きく改善された.

(3) 分極曲線の測定結果より, ゼラチンと塩化物イオンを 共存させると $\mathrm{Cu}$ 電析の分極抵抗 $\mathrm{d} E / \mathrm{d} i$ が大きくなっている ことが分かった。この分極抵抗の増加により, 均一電着性が 改善されたと考えられる. 微量添加のチ才尿素には銅電析に 対する復極作用が認められ, 電析物凹部での電析促進による 平滑化効果が期待される.

\section{文献}

1) C. L. Mantell: Electrochemical Engineering, (McGraw-Hill Book Company, Inc., New York, NY, U.S.A., 1960) pp. 142-167, 185192, 210-224.
2) Hitetsu Kinzoku Seiren, (Nippon Kinzoku Gakkai, Sendai, 1980) p. 228, 241.

3) Denki Kagaku Binran, (Denki Kagaku Kyokai, Maruzen, Tokyo, 1985) pp. 308-327.

4) B. Veilleux, A. M. Lafront and E. Ghali: Can. Metall. Q. 41 (2002) 47-62.

5) K. Shimokawa: Thesis for doctoral degree, (Kyoto University, 2013) pp. 19-22.

6) S. Goto, I. Asakura and C. Oshima: J. Min. Metall. Inst. Jpn. 91 (1975) $131-136$

7) S. Goto, O. Ogawa, I. Asakura and C. Oshima: J. Min. Metall. Inst. Jpn. 88(1972) 99-102.

8) C. Imai and S. Yashima: J. Min. Metall. Inst. Jpn. 73(1957) 301305.

9) H. Nakano, S. Oue, T. Ohgai, K. Izumi, T. Akiyama and H. Fukushima: J. MMIJ 119(2003) 663-667.

10) K. Shimokawa, K. Kawaguchi, K. Nishida, K. Murase, H. Sugimura and Y. Awakura: J. MMIJ 128(2012) $155-159$

11) H. Kuboyama, H. Nakano, S. Oue, H. Fukushima and S. Kobayashi: J. MMIJ 125(2009) 62-67.

12) P. Laforest and M. Moats: Proc. Copper 2016, (The Mining and Materials Processing Institute of Japan, 2016) pp. 2064-2075.

13) K. Shimokawa, D. Tetsuka, K. Shikada, K. Murase, H. Sugimura and Y. Awakura: J. MMIJ 129(2013) 72-77.

14) K. Shimokawa, M. Narita, I. Sumida, K. Murase, H. Sugimura and Y. Awakura: J. MMIJ 126(2010) 697-700.

15) A. Rodchanarowan and M. L. Free: Mater. Trans. 53(2012) 16951698.

16) H. Nakano, S. Oue, K. Aoya, H. Kuboyama, H. Fukushima and S. Kobayashi: J. MMIJ 123(2007) 165-170.

17) H. Nakano, S. Oue, Y. Tsuyama, H. Fukushima, S. Kobayashi and K. Tomioka: J. MMIJ 127 (2011) 662-666.

18) H. Nakano, S. Oue, T. Nishino, H. Kuboyama, H. Fukushima and S. Kobayashi: J. MMIJ 128(2012) 590-595.

19) K. Ando, N. Tsuchida and H. Komi: Shigen-to-Sozai 118(2002) 86-90.

20) H. M. Abbas and S. T. Najim: Int. J. Curr. Microbiol. App. Sci. 6(2017) $270-284$

21) M. Matlosz, C. Creton, C. Clerc and D. Landol: J. Electrochem. Soc. 134(1987) 3015-3022.

22) M. Chikuma: J. Surf. Finish. Soc. Jpn. 44(1993) 583-588. 